\title{
PENGARUH VARIASI INDUKTOR TERHADAP HASIL OPERASI CCM DAN DCM DC CHOPPER TIPE ZETA BERBASIS IC TL494
}

\author{
Tegar Ubo Laksono*), Trias Andromeda dan Bambang Winardi \\ Departemen Teknik Elektro, Universitas Diponegoro, Semarang \\ Jln. Prof. Sudharto, SH, Kampus UNDIP Tembalang, Semarang 50275, Indonesia \\ ${ }^{*}$ E-mail: tegarubolaksono@gmai.com
}

\begin{abstract}
Abstrak
Kebutuhan konversi tegangan arus searah semakin banyak digunakan dibidang industri dalam skala besar maupun kecil. Salah satu cara untuk mengkonversi tegangan arus searah konstan ke tegangan arus searah yang dapat divariasikan adalah dengan menggunakan DC Chopper. DC chopper terdiri dari beberapa konfigurasi yang sering digunakan yaitu buck, boost, buck - boost, cuk, sepic dan zeta. DC Chopper mempunyai 2 mode operasi kerja, yaitu mode DCM (Discontinuous Conduction Mode) dan mode CCM (Continuous Conduction Mode). Banyak penelitian yang memanfaatkan kinerja DC Chopper sebagai penyedia catu daya tegangan searah. Namun dalam penelitian, karakteristik dan mode kerja konverter tidak diperhatikan dan dibahas, sehingga tidak jelas mode operasi apa yang digunakan dalam konverter. Pada Penelitian ini dibuat DC Chopper tipe zeta. Zeta converter tersebut menggunakan MOSFET sebagai saklar elektronik yang dipicu oleh rangkaian kontrol IC TL494. Respon keluaran zeta converter yang akan dibahas meliput respon arus dan tegangan keluaran serta efisiensi daya pada mode operasi DCM dan CCM. Berdasarkan hasil percobaan, pengujian mode DCM menghasilkan tegangan keluaran maksimal sebesar 96,3 V, dan nilai efisiensi tertinggi yang dihasilkan sebesar 90,368 \%. Pengujian mode CCM menghasilkan tegangan keluaran maksimal sebesar $86,5 \mathrm{~V}$, dan nilai efisiensi tertinggi yang dihasilkan sebesar 91,66287\%.
\end{abstract}

Kata kunci : DC Chopper, Zeta Converter, DCM, CCM.

\begin{abstract}
The need for direct current voltage conversion is increasingly used in the field of industry in large and small scale. One way to convert a constant direct current voltage to a uniform current voltage that can be varied is to use DC Chopper. DC chopper consists of several commonly used configurations: buck, boost, buck - boost, cuk, sepic and zeta. DC Chopper has 2 working mode modes, namely DCM (Discontinuous Conduction Mode) mode and CCM (Continuous Conduction Mode) mode. Many studies have utilized DC Chopper's performance as a unidirectional power supply provider. However, in the study, the characteristics and working modes of the converter are not addressed and discussed, so it is unclear what mode of operation is used in the converter. In this Research made DC Chopper type zeta. The Zeta converter uses a MOSFET as an electronic switch triggered by a TL494 control circuit IC. The zeta converter output response to be covered covers the current and output voltage response and power efficiency in DCM and CCM modes of operation. Based on the experimental results, the DCM mode test produces a maximum output voltage of $96.3 \mathrm{~V}$, and the highest efficiency value generated is $90.368 \%$. The CCM mode test produces a maximum output voltage of $86.5 \mathrm{~V}$, and the highest efficiency value generated is $91.66287 \%$.
\end{abstract}

Keywords: DC Chopper, Zeta Converter, DCM, CCM.

\section{Pendahuluan}

Saat ini, kebanyakan peralatan-peralatan elektronik dijalankan oleh sumber arus searah (DC). Beberapa teknologi penyediaan tegangan DC mulai dikembangkan dari menggunakan baterai, photovoltaic sampai metode penyearah dari sumber AC 1 fasa. Namun demikian, kemajuan yang dialami dibidang elektronika daya masih terus menerus diharapkan untuk dapat menjawab tantangan yang berupa kompleksitas sistem elektronika modern yang semakin tinggi. Sebagai bagian dari jawaban terhadap tantangan tersebut adalah dengan digunakannya DC Chopper pada pengubah daya dengan pensaklaran, yang bertujuan untuk menciptakan sistem pengubah daya 
DC yang jauh lebih efisien, variabel dan lebih handal dari metoda konvensional. DC chopper mempunyai 2 operasi kerja yaitu mode DCM (Discontinuous Conduction Mode) dan mode CCM (Continuous Conduction Mode). Mode DCM adalah mode dimana arus induktor pada konverter mencapai nol, atau tidak continue. Mode CCM adalah mode operasi dimana arus induktor pada konverter mengalir secara continue, dalam artian tidak pernah mencapai nol. Dalam penelitian sebelumnya, catu daya dc-dc konverter telah dibuat. Namun dalam penelitian tersebut hanya mengutamakan nilai tegangan keluaran saja, tanpa meneliti kinerja dc-dc konverter tersebut. Mode operasi DCM atau CCM tidak dijelaskan apakah digunakan dalam penelitian tersebut. Pada referensi [1] dibuat perancangan zeta converter yang dilengkapi Power Factor Correction pada Aplikasi Pengaturan Kecepatan Motor Brushless DC. Pada referensi [2] membahas mengenai simulasi dan analisis kinerja CCM zeta converter dengan kontrol PID. Pada penelitian terakhir [3] dibuat penelitian yang membahas mengenai peningkatan kualitas daya pada zeta converter untuk Motor Brushless. Catu daya zeta converter telah dibuat untuk berbagai aplikasi. Namun dalam penelitian tersebut tidak dibahas karakteristik DC chopper zeta yang digunakan. Dalam penelitian sebelumnya ketika DC chopper telah menghasilkan tegangan yang diharapkan maka dianggap masalah DC chopper telah selesai. Permasalahan tegangan dan arus DC tidak dibahas lebih lanjut dan tidak diteliti mode arus yang digunakan.

\section{Metode}

\subsection{Perancangan Perangkat Keras}

Perancangan Penelitian ini terdiri dari rangkaian penyearah, rangkaian konverter arus searah zeta, dan rangkaian pembangkit sinyal PWM.

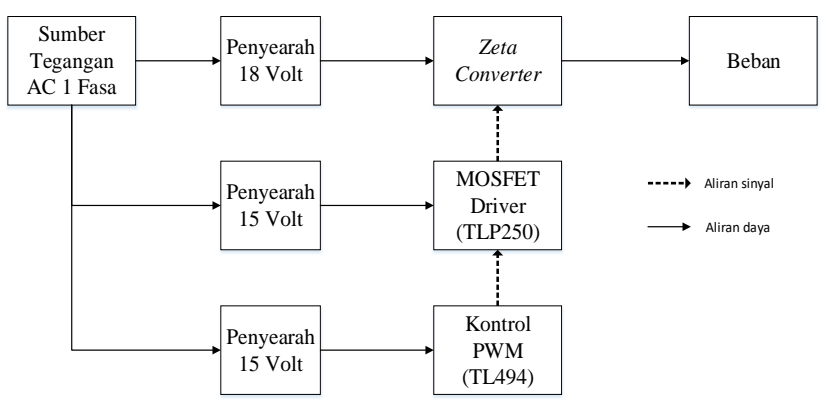

Gambar 1. Blok Diagram Alat

\subsection{Penyearah}

Rangkaian penyearah pada Penelitian ini digunakan sebagai suplai rangkaian daya konverter arus searah zeta dan suplai rangkaian pembangkit sinyal PWM beserta driver MOSFET.

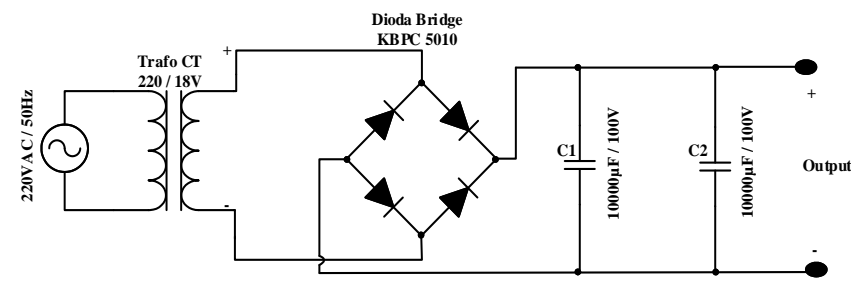

(a)

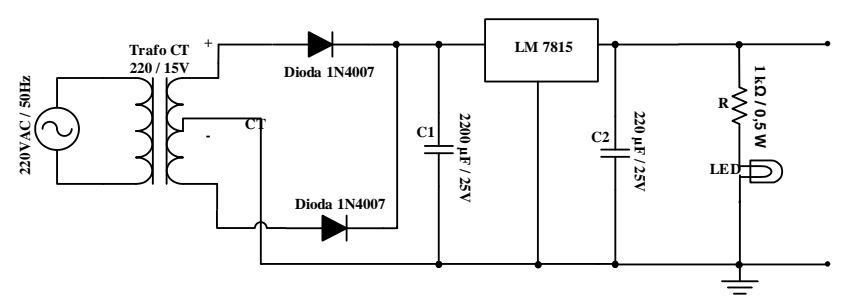

(b)

Gambar 2. (a)Penyearah dengan diode bridge (b)Penyearah Dengan Center Tap

Gambar 2 merupakan rangkaian penyearah yang digunakan pada Penelitian ini. Gambar 2 (a) merupakan penyarah 1 fasa gelombang penuh tak terkontrol diode bridge untuk suplai daya konverter arus searah zeta, sementara Gambar 2 (b) merupakan penyearah 1 fasa gelombang penuh $\mathrm{CT}$ untuk suplai rangkaian kontrol PWM IC TL494 beserta MOSFET driver TLP250.

\subsection{Konverter Arus Searah Zeta}

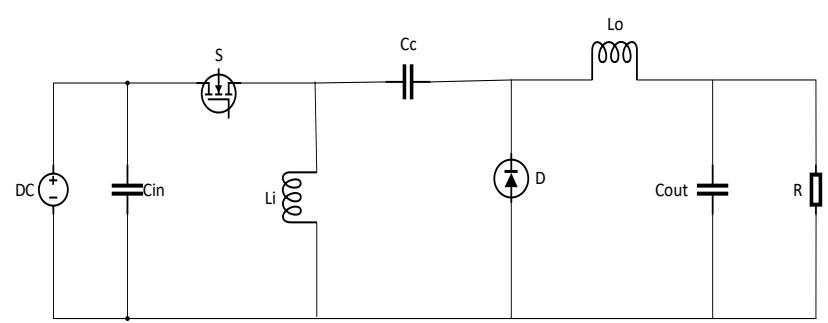

Gambar 3. Rangkaian Konverter Arus Searah Zeta[7]

Rangkaian konverter arus searah zeta tersusun dari komponen-komponen berikut:

1. Sumber Tegangan DC $\left(V_{i n}\right)$

Sumber tegangan yang digunakan sebagai suplai daya konverter berasal dari keluaran rangkaian penyarah 1 fasa gelombang penuh tak terkontrol sebesar $25.45 \mathrm{~V}$.

2. Saklar

MOSFET yang digunakan adalah MOSFET IRFP 260N yang mempunyai tegangan Drain-Source sebesar $200 \mathrm{~V}$ dan kemampuan arus drain maksimal 46A, sehingga pemakaian MOSFET tipe IRFP 260N ini aman untuk dipakai karena arus rata-rata yang dialirkan rangkaian daya yaitu $1 \mathrm{~A}$

3. Dioda

Dioda yang digunakan adalah MUR1560. Dioda ini 
dipilih karena mempunyai sifat ultrafast recovery dengan waktu pemulihan $60 \mathrm{~ns}$.

4. Induktor

Induktor yang digunakan pada konverter arus searah ini diperhitungkan nilainya untuk disesuaikan dengan parameter lain yang berhubungan. Induktor yang digunakan merupakan induktor jenis solenoida yang dibuat dari kawat tembaga yang dililitkan pada inti ferit.

- $L_{i}$

Nilai $L_{i}$ merupakan penentu apakah DC chopper tersebut beroperasi pada mode CCM atau DCM. Batas minimum untuk mode operasi CCM adalah[1]:

$$
\begin{aligned}
L i_{\min } & =\frac{V_{I N} \cdot D}{\Delta I_{L i} \cdot f_{s}} \\
L i_{\text {min }} & =\frac{25.45 \times 0,797}{0,3 \times 25000}=3,2 \mathrm{mH}
\end{aligned}
$$

Batas minimum untuk mode operasi DCM adalah:

$$
\begin{aligned}
& L i_{\text {min }}=\frac{V_{I N} \cdot D}{\Delta I_{L i} \cdot f_{S}} \\
& L i_{\text {min }}=\frac{25.45 \times 0,797}{1 \times 25000} \\
& L i_{\text {min }}=0,811 \mathrm{mH}
\end{aligned}
$$

- $L_{o}$

Induktor Lo berfungsi untuk mereduksi ripple arus pada sisi output DC chopper tipe zeta. Nilai $L o_{\text {min }}$ yang digunakan adalah[1]:

$$
\begin{aligned}
L o_{\text {min }} & =\frac{V_{D C} \cdot D}{\Delta I_{L o} \cdot f S} \\
L \boldsymbol{o}_{\text {min }} & =\frac{100 \times \mathbf{0 , 7 0 2}}{\mathbf{0 , 3} \times \mathbf{2 5 0 0 0}} \\
L o_{\text {min }} & =2,7 \mathrm{mH}
\end{aligned}
$$

Jadi, dari perhitungan batas minimum ${ }^{L i}{ }_{\min }$ dan ${ }^{L o}{ }_{\min } \mathrm{di}$ atas, maka nilai masing - masing induktor yang digunakan adalah

$$
\begin{array}{ll}
\text { Mode DCM } & \text { Mode CCM } \\
L_{i}=0,811 \mathrm{mH} & L_{i}=3,2 \mathrm{mH} \\
L_{o}=2,7 \mathrm{mH} & L_{o}=2,7 \mathrm{mH}
\end{array}
$$

Pemilihan nilai induktor tersebut agar sistem Zeta Converter bekerja pada Continuous Current Mode (CCM) dan Discontinuous Current Mode (CCM) karena tidak terpaut jauh dari batas minimum.

\section{Kapasitor}

Kapasitor Cc berfungsi sebagai kapasitor coupled sedangkan kapasitor Cout berfungsi sebagai filter tegangan untuk membatasi ripple tegangan yang disebabkan kenaikan nilai beban.

$C_{c}=\frac{D \cdot I_{\text {out }}}{\Delta V_{C c} \cdot f S}$

$C_{c}=\frac{0.797 \times 1.27}{0.2 \times 25000}=202.43 \mu \mathrm{F}$

Pada realisasinya kapasitor yang dipasang adalah 220 $\mu \mathrm{F}$.

Sedangkan untuk menentukan nilai kapasitor keluaran (Cout).

$$
\begin{aligned}
C_{\text {out }} & =\frac{\Delta I_{L 2}}{8 . \Delta V_{\text {Cout }} \cdot f s} \\
C_{\text {out }} & =\frac{0.3}{8 \times 0.01 \times 25000} \\
C_{\text {out }} & =150 \mu \mathrm{F}
\end{aligned}
$$

Pada realisasinya kapasitor yang dipasang sebesar 220 $\mu \mathrm{F}$. Pemilihan kapasitor yang lebih besar dari nilai kapasitansi kapasitor perhitungan agar keluaran ripple tegangan keluaran zeta konverter kecil.

\subsection{Rangkaian PWM IC TL494}

PWM digunakan untuk pemicuan MOSFET pada rangkaian daya buck converter. Penelitian ini menggunakan IC TL494 sebagai IC pemicuan MOSFET. Gambar 4 merupakan rangkaian IC TL494.

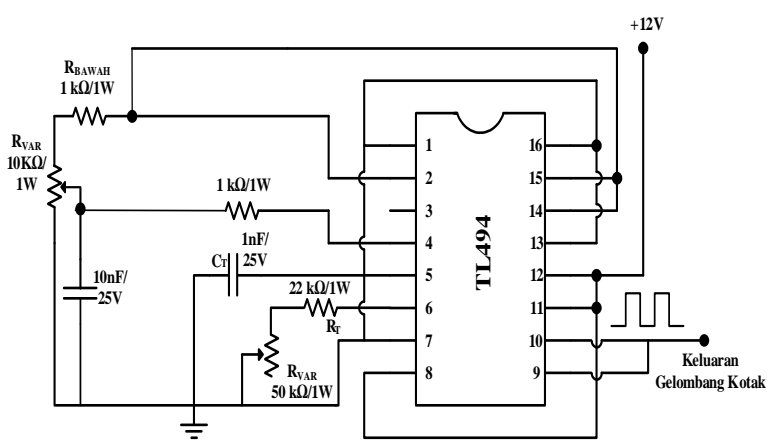

Gambar 4. Rangkaian kontrol IC TL494.

Frekuensi osilasi pada pemicuan ini diatur dengan kaki 5 (CT) dan 6 (RT) dari IC TL 494, dimana RT adalah Resistor Timer dan CT adalah Capacitor Timer.

Besar nilai komponen yang digunakan adalah:

$$
\begin{array}{ll}
\text { CT } & : 1 \mathrm{nF} / 25 \mathrm{~V} \\
\mathrm{RT} & : 22 \mathrm{k} \Omega / 1 \mathrm{~W} \\
\mathrm{R}_{\text {Var }} & : 50 \mathrm{k} \Omega / 1 \mathrm{~W}
\end{array}
$$

Besar frekuensi osilasi maksimal dari rangkaian PWM dapat ditentukan dengan Persamaan (1)[10]: 


$$
f=\frac{1,1}{R_{T} \cdot C_{T}}
$$

Dimana: $\mathrm{RT}=$ Resistor Timer

$$
\mathrm{CT}=\text { Capacitor Timer }
$$

Sesuai dengan Persamaan (1), maka:

$$
\begin{aligned}
\mathrm{f}_{\text {osc }(\max )}= & \frac{1.1}{22000.10 .10^{-9}} \\
& =50 \mathrm{kHz}\left(\mathrm{R}_{\text {var }}=0 \Omega\right) \\
\mathrm{f}_{\text {osc }(\min )}= & \frac{1.1}{72000.10 .10^{-9}} \\
= & 15277,77 \mathrm{~Hz}\left(\mathrm{R}_{\text {var }}=50 \mathrm{k} \Omega\right)
\end{aligned}
$$

\subsection{Rangkaian MOSFET driver TLP250}

Rangkaian MOSFET driver TLP250 digunakan sebagai penguat sinyal keluaran dan pemisah antara rangkaian kontrol IC TL494 dan rangkaian konverter arus searah zeta.

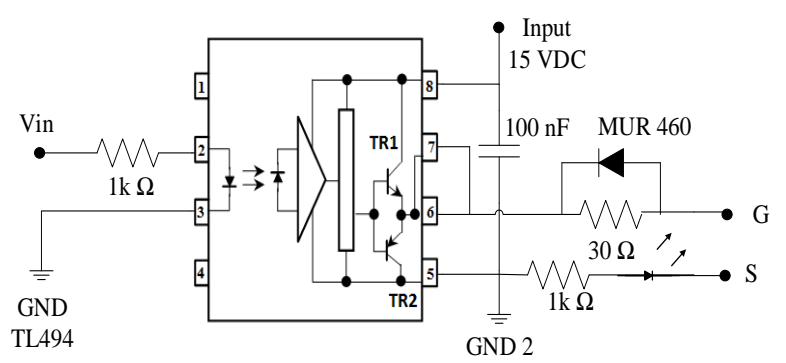

Gambar 5. Rangkaian MOSFET driver

Pada Gambar 5, TLP250 mendapat suplai Vec $15 \mathrm{~V}$ berasal dari rangkaian penyearah gelombang penuh CT. Pada rangkaian TLP250 juga terdapat kapasitor bypass $100 \mathrm{nF}$ antara power supply IC dengan ground output. Resistor $22 \Omega$ yang terhubung pin 6 dan 7 menuju gate MOSFET berfungsi sebagai pembatas arus sinyal keluaran TLP250.

\section{Hasil dan Analisa \\ 3.4. Pengujian Rangkaian Zeta Converter}

Pengujian Zeta Converter meliputi pengujian tegangan keluaran, pengujian dengan variasi jenis beban, dan perhitungan efisiensi.

\subsubsection{Pengujian Tegangan Keluaran}

3.4.1.1. Pengujian Tegangan Keluaran Beban Resistif

Pada Tabel 1 berikut dapat dilihat hasil pengujian tegangan keluaran Zeta Converter beban resistif.
Tabel 1. Hasil pengujian tegangan keluaran beban resistif

\begin{tabular}{cccc}
\hline Duty cycle (\%) & Frekuensi & Vin (Volt) & Vout (Volt) \\
\hline 10 & 25 & 26,9 & 2,73 \\
20 & 25 & 26,4 & 6,05 \\
30 & 25 & 26,05 & 10,6 \\
40 & 25 & 25,4 & 16,08 \\
50 & 25 & 24,2 & 22,5 \\
60 & 25 & 22,5 & 31,3 \\
70 & 25 & 19,8 & 40,3 \\
80 & 25 & 15,8 & 45,3 \\
\hline
\end{tabular}

Berdasarkan Tabel 1 terlihat bahwa hasil pengujian sudah sesuai teori. Ketika diberi picuan dengan duty cycle dibawah $50 \%$ maka tegangan keluaran akan lebih kecil dari pada tegangan masukan. Sedangkan pada saat diberi picuan dengan duty cycle sebesar $50 \%$ atau lebih, tegangan keluaran akan sama dengan atau lebih besar dari tegangan masukan.

\subsubsection{Pengujian Tegangan Keluaran Beban Induktif}

Hasil pengujian tegangan keluaran beban induktif ditunjukan pada Tabel 2.

Tabel 2. Hasil pengujian tegangan keluaran beban induktif

\begin{tabular}{cccc}
\hline $\begin{array}{c}\text { Duty cycle } \\
\text { (\%) }\end{array}$ & Frekuensi & Vin (Volt) & Vout (Volt) \\
\hline 10 & 25 & 26,74 & 2,6 \\
20 & 25 & 26,58 & 6,25 \\
30 & 25 & 26,38 & 10,76 \\
40 & 25 & 26,14 & 17,06 \\
50 & 25 & 25,8 & 25 \\
60 & 25 & 25,3 & 36,83 \\
70 & 25 & 24,36 & 55,2 \\
80 & 25 & 22,74 & 86,5 \\
\hline
\end{tabular}

Berdasarkan Tabel 2 terlihat bahwa hasil pengujian sudah sesuai teori. Ketika diberi picuan dengan duty cycle dibawah $50 \%$ maka tegangan keluaran akan lebih kecil dari pada tegangan masukan. Sedangkan pada saat diberi picuan dengan duty cycle sebesar $50 \%$ atau lebih, tegangan keluaran akan sama dengan atau lebih besar dari tegangan masukan.

\subsubsection{Pengujian Zeta Converter dengan Variasi Jenis Beban.}

Pengujian ini dilakukan untuk mengetahui pengaruh jnis beban pada kinerja zeta converter. Jenis beban yang digunakan pada pengujian ini adalah beban resistif dan beban induktif. 


\subsubsection{1/ Pengujian dengan Beban Resistif Mode DCM}

Tabel 3. Data pengukuran zeta converter beban resisitif mode DCM

\begin{tabular}{ccccccc}
\hline $\begin{array}{l}\text { Duty } \\
\text { Cycle }\end{array}$ & V $_{\text {in }}(\mathbf{V})$ & I $_{\text {in }}(\mathbf{A})$ & \multicolumn{2}{c}{$\mathrm{V}_{\text {out }}(\mathrm{V})$} & \multicolumn{2}{c}{$\mathrm{I}_{\text {out }}(\mathbf{A})$} \\
\hline $10 \%$ & 26,7 & 0,026 & 5,84 & - & 0,097 & - \\
$20 \%$ & 26,05 & 0,096 & 11,4 & - & 0,18 & - \\
$30 \%$ & 25,58 & 0,2 & 16,35 & - & 0,27 & - \\
$40 \%$ & 24,8 & 0,33 & 20,8 & - & 0,34 & - \\
$50 \%$ & 24 & 0,53 & 25,8 & - & 0,42 & - \\
$60 \%$ & 22,86 & 0,85 & 32,2 & - & 0,53 & - \\
$70 \%$ & 20 & 1,72 & - & 42,2 & - & 0,68 \\
$80 \%$ & 15,2 & 3,39 & - & 49 & - & 0,77 \\
\hline
\end{tabular}

\subsubsection{Pengujian dengan Beban Resistif Mode CCM}

Tabel 4. Data pengukuran zeta converter beban resisitif mode CCM

\begin{tabular}{ccccccc}
\hline $\begin{array}{c}\text { Duty } \\
\text { cycle }\end{array}$ & V $_{\text {in }}(\mathrm{V})$ & lin $_{\text {in }}(\mathbf{A})$ & \multicolumn{2}{c}{$\mathrm{V}_{\text {out }}(\mathrm{V})$} & \multicolumn{2}{c}{$\mathrm{I}_{\text {out }}(\mathrm{A})$} \\
\hline $10 \%$ & 26,9 & 0,006 & 2,73 & - & 0,05 & - \\
$20 \%$ & 26,4 & 0,027 & 6,05 & - & 0,1 & - \\
$30 \%$ & 26,05 & 0,079 & 10,6 & - & 0,17 & - \\
$40 \%$ & 25,4 & 0.184 & - & 16,08 & - & 0,26 \\
$50 \%$ & 24,2 & 0,37 & - & 22,5 & - & 0,37 \\
$60 \%$ & 22,5 & 0,79 & - & 31,3 & - & 0,51 \\
$70 \%$ & 19,8 & 1,59 & - & 40,3 & - & 0,66 \\
$80 \%$ & 15,8 & 3,01 & - & 45,3 & - & 0,76 \\
\hline
\end{tabular}

\subsubsection{Pengujian dengan Beban Induktif Mode DCM}

Tabel 5. Data pengukuran zeta converter beban indukitif mode DCM.

\begin{tabular}{ccccccc}
\hline Duty cycle & $\mathbf{V}_{\text {in }}(\mathbf{V})$ & lin $(\mathbf{A})$ & \multicolumn{2}{c}{$\mathbf{V}_{\text {out }}(\mathbf{V})$} & \multicolumn{2}{c}{$\mathrm{I}_{\text {out }}(\mathbf{A})$} \\
& & & DCM & CCM & DCM & CCM \\
\hline $10 \%$ & 26,8 & 0,028 & 4,8 & - & 0,12 & - \\
$20 \%$ & 25,6 & 0,093 & 14,6 & - & 0,14 & - \\
$30 \%$ & 25,4 & 0,195 & 26,6 & - & 0,164 & - \\
$40 \%$ & 24,64 & 0,33 & 44 & - & 0,167 & - \\
$50 \%$ & 23,68 & 0,51 & 57,7 & - & 0,18 & - \\
$60 \%$ & 22,93 & 0,7 & 72 & - & 0,195 & - \\
$70 \%$ & 22,3 & 0,875 & 84,5 & - & 0,2 & - \\
$80 \%$ & 21,54 & 1,07 & 96,3 & - & 0,203 & - \\
\hline
\end{tabular}

\subsubsection{Pengujian dengan Beban Induktif Mode CCM}

Tabel 6. Data pengukuran zeta converter beban indukitif mode CCM.

\begin{tabular}{ccccccc}
\hline $\begin{array}{c}\text { Duty } \\
\text { cycle }\end{array}$ & $\mathbf{V}_{\text {in }}(\mathbf{V})$ & $\mathrm{l}_{\text {in }}(\mathrm{A})$ & \multicolumn{2}{c}{$\mathrm{V}_{\text {out }}(\mathrm{V})$} & \multicolumn{2}{c}{ lout } \\
DCM & CCM & DCM & CCM \\
\hline $10 \%$ & 26,74 & 0,013 & 2,6 & - & 0,11 & - \\
$20 \%$ & 26,58 & 0,03 & 6,25 & - & 0,112 & - \\
$30 \%$ & 26,38 & 0,052 & 10,76 & - & 0,116 & - \\
$40 \%$ & 26,14 & 0,089 & 17,06 & - & 0,125 & - \\
$50 \%$ & 25,8 & 0,143 & - & 25 & - & 0,137 \\
$60 \%$ & 25,3 & 0,238 & - & 36,83 & - & 0,153 \\
$70 \%$ & 24,36 & 0,416 & - & 55,2 & - & 0,172 \\
$80 \%$ & 22,74 & 0,792 & - & 86,5 & - & 0,189 \\
\hline
\end{tabular}

\subsubsection{Perhitngan Efisiensi Zeta Converter}

$\eta=\frac{P_{\text {out }}}{P_{\text {in }}} \times 100 \%$

Dimana:

$P_{\text {in }}=V_{\text {in }} x I_{\text {in }}$

$P_{\text {out }}=V_{\text {out } x} I_{\text {out }}$

\subsubsection{Perhitungan Efisiensi Zeta Converter pada Beban Resistif}

Tabel 7. Data pengukuran zeta converter beban resistif

\begin{tabular}{ccccccccc}
\hline $\begin{array}{c}\text { Duty } \\
\text { Cycl }\end{array}$ & \multicolumn{2}{c}{ Vin (V) } & \multicolumn{2}{c}{$\operatorname{lin}(\mathbf{A})$} & \multicolumn{2}{c}{ Vout (V) } & \multicolumn{2}{c}{ lout (A) } \\
e(\%) & & CCM & DCM & CCM & DCM & CCM & DCM & CCM \\
\hline 10 & 26,7 & 26,9 & 0,026 & 0,006 & 5,84 & 2,73 & 0,09 & 0,05 \\
20 & 26,05 & 26,4 & 0,096 & 0,027 & 11,4 & 6,05 & 0,18 & 0,1 \\
30 & 25,58 & 26,05 & 0,2 & 0,079 & 16,35 & 10,6 & 0,27 & 0,17 \\
40 & 24,8 & 25,4 & 0,33 & 0,184 & 20,8 & 16,08 & 0,34 & 0,26 \\
\hline
\end{tabular}

Dengan menggunakan Tabel 7, daya dan efisiensi zeta converter dapat dihitung dengan cara perhitungan yang sama menggunakan perhitungan efisiensi. Berikut data perhitungan daya dan efisiensi zeta converter beban resistif.

Tabel 8. Data Perhitungan daya dan efisiensi zeta converter beban resistif

\begin{tabular}{|c|c|c|c|c|c|c|}
\hline \multirow{2}{*}{$\begin{array}{c}\text { Duty } \\
\text { Cycle } \\
(\%)\end{array}$} & \multicolumn{2}{|c|}{ Pin (W) } & \multicolumn{2}{|c|}{ Pout (W) } & \multicolumn{2}{|c|}{ Efisiensi (\%) } \\
\hline & DCM & $\mathrm{CCM}$ & $\mathrm{DCM}$ & $\mathrm{CCM}$ & $\mathrm{DCM}$ & CCM \\
\hline 10 & 0,6942 & 0,1614 & 0,56648 & 0,1365 & $\begin{array}{c}81,601 \\
84\end{array}$ & 84,5725 \\
\hline 20 & 2,5008 & 0,7128 & 2,052 & 0,605 & $\begin{array}{c}82,053 \\
74\end{array}$ & 84,8765 \\
\hline 30 & 5,116 & 2,05795 & 4,4145 & 1,802 & $\begin{array}{c}86,288 \\
12\end{array}$ & 87,56287 \\
\hline 40 & 8,184 & 4,6736 & 7,072 & 4,1808 & $\begin{array}{c}86,412 \\
5\end{array}$ & 89,45567 \\
\hline
\end{tabular}

Berdasarkan Tabel 8 dapat disajikan grafik perbandingan duty cycle - efisiensi dalam Gambar 6.

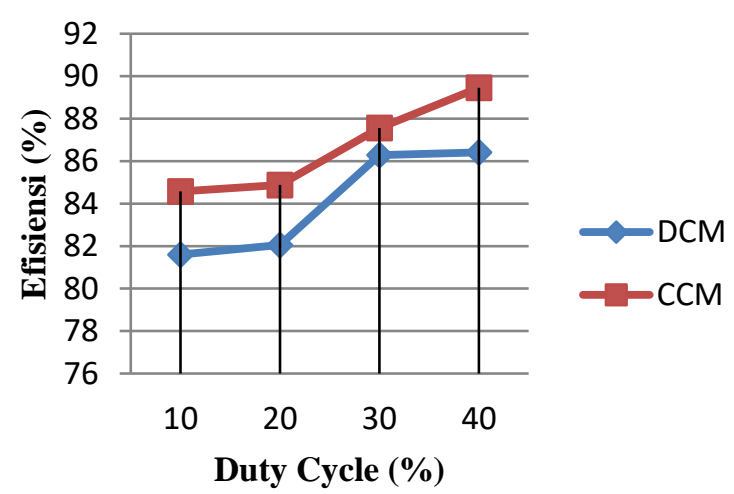

Gambar 6. Grafik perbandingan duty cycle - efisiensi zeta converter beban resistif mode DCM dan CCM 
Gambar 6 menunjukkan nilai efisiensi tertinggi yang dihasilkan zeta converter beban resistif saat mode DCM terjadi pada saat duty cycle $40 \%$ yaitu sebesar $86,4125 \%$ dan saat mode CCM terjadi pada saat duty cycle $40 \%$ yaitu sebesar $89,45567 \%$. Dari hasil perbandingan dapat diketahui bahwa nilai efisiensi zeta converter beban resistif saat mode CCM memiliki nilai efisiensi lebih tinggi dari pada saat mode DCM, bahkan pasa semua variasi duty cycle. Hal ini menunjukkan bahwa mode CCM lebih unggul dibandingkan mode DCM jika ditinjau dari nilai efisiensi yang dihasilkan.

Nilai efisiensi yang tidak mencapai $100 \%$ mengindikasikan bahwa pada zeta converter terdapat rugi daya. Rugi daya tersebut dapat disebabkan oleh rugi rugi jumper dan rugi - rugi akibat adanya resistansi dalam pada komponen elektronika yang digunakan.

\subsubsection{Perhitungan Efisiensi Zeta Converter Beban Induktif}

Tabel 9. Data pengukuran zeta converter beban induktif

\begin{tabular}{ccccccccc}
\hline $\begin{array}{c}\text { Duty } \\
\text { Cycl } \\
\text { e(\%) }\end{array}$ & \multicolumn{2}{c}{ DCM (V) } & \multicolumn{2}{c}{ lin (A) } & \multicolumn{2}{c}{ Vout (V) } & \multicolumn{2}{c}{ lout (A) } \\
\hline 10 & 26,8 & 26,74 & 0,028 & 0,013 & 4,8 & 2,6 & 0,12 & 0,11 \\
20 & 25,6 & 26,58 & 0,093 & 0,03 & 14,6 & 6,25 & 0,14 & 0,11 \\
& & & & & & & 0,16 & 0,11 \\
30 & 25,4 & 26,38 & 0,195 & 0,052 & 26,6 & 10,76 & 4 & 6 \\
& & & & & & & 0,16 & 0,12 \\
40 & 24,64 & 26,14 & 0,33 & 0,089 & 44 & 17,06 & 7 & 5 \\
\hline
\end{tabular}

Dengan menggunakan Tabel 9, daya dan efisiensi zeta converter dapat dihitung dengan cara perhitungan yang sama menggunakan perhitungan efisiensi. Berikut data perhitungan daya dan efisiensi zeta converter beban resistif.

Tabel 10. Data Perhitungan daya dan efisiensi zeta converter beban induktif

\begin{tabular}{|c|c|c|c|c|c|c|}
\hline \multirow{2}{*}{$\begin{array}{c}\text { Duty } \\
\text { Cycle } \\
\text { (\%) }\end{array}$} & \multicolumn{2}{|c|}{ Pin (W) } & \multicolumn{2}{|c|}{ Pout (W) } & \multicolumn{2}{|c|}{ Efisiensi (\%) } \\
\hline & DCM & $\mathrm{CCM}$ & $\mathrm{DCM}$ & $\mathrm{CCM}$ & $\mathrm{DCM}$ & $\mathrm{CCM}$ \\
\hline 10 & 0,7504 & 0,34762 & 0,576 & 0,286 & $\begin{array}{c}76,759 \\
06\end{array}$ & 82,27375 \\
\hline 20 & 2,3808 & 0,7974 & 2,044 & 0,7 & $\begin{array}{c}85,853 \\
49\end{array}$ & 87,7853 \\
\hline 30 & 4,953 & 1,37176 & 4,3624 & 1,24816 & $\begin{array}{c}88,075 \\
91\end{array}$ & 90,98968 \\
\hline 40 & 8,1312 & 2,32646 & 7,348 & 2,1325 & 90,368 & 91,66287 \\
\hline
\end{tabular}

Dari Tabel 10 dapat disajikan grafik perbandingan duty cycle - efisiensi dalam Gambar 7.

Gambar 7 menunjukkan nilai efisiensi tertinggi yang dihasilkan zeta converter beban induktif saat mode DCM terjadi pada saat duty cycle $40 \%$ yaitu sebesar $93,19196 \%$ dan saat mode CCM terjadi pada saat duty cycle $40 \%$ yaitu sebesar $91,66287 \%$. Dari hasil perbandingan dapat diketahui bahwa nilai efisiensi zeta converter beban induktif saat mode CCM memiliki nilai efisiensi lebih tinggi dari pada saat mode DCM, bahkan pasa semua variasi duty cycle. Hal ini menunjukkan bahwa mode CCM lebih unggul dibandingkan mode DCM jika ditinjau dari nilai efisiensi yang dihasilkan.

Nilai efisiensi yang tidak mencapai $100 \%$ mengindikasikan bahwa pada zeta converter terdapat rugi daya. Rugi daya tersebut dapat disebabkan oleh rugi rugi jumper dan rugi - rugi akibat adanya resistansi dalam pada komponen elektronika yang digunakan.

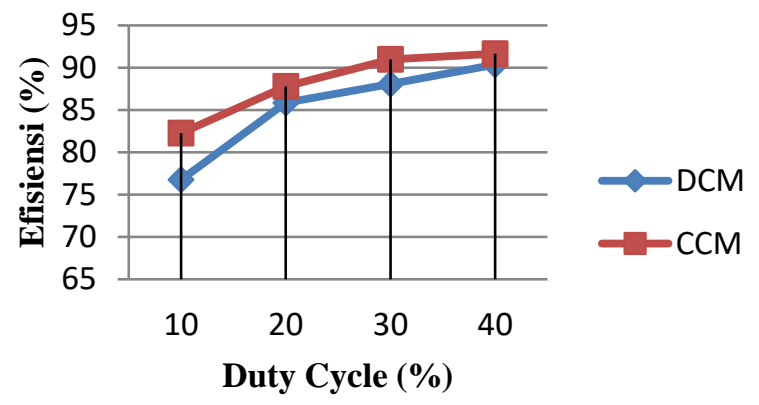

Gambar 7. Grafik perbandingan duty cycle - efisiensi zeta converter beban induktif mode DCM dan CCM

\section{Kesimpulan}

Zeta Converter telah berhasil dibuat dan dapat menghasilkan tegangan keluaran lebih besar atau lebih kecil dari tegangan masukan dengan mengatur besar lebar pulsa (duty cycle) dari rangkaian kontrol PWM (Pulsa Width Modulation). Perbedaan mode operasi CCM dan DCM pada zeta converter terletak pada nilai induktansi induktor yang digunakan. Pada mode operasi CCM digunakan induktor dengan nilai induktansi $\mathrm{Li}=3,2 \mathrm{mH}$ dan Lo $=2,7 \mathrm{mH}$. Pada mode operasi DCM digunakan induktor dengan nilai induktansi $\mathrm{Li}=0,7 \mathrm{mH}$ dan $\mathrm{Lo}=$ 2,7 $\mathrm{mH}$. Pengujian arus induktor menunjukkan bahwa pada beban resistif, saat menggunakan induktor dengan mode DCM bekerja pada duty cycle $0 \%-60 \%$ dan pada duty cycle $61 \%$ - $80 \%$ beralih pada mode CCM. Sedangkan saat menggunakan induktor dengan mode CCM bekerja pada duty cycle $31 \%$ - $80 \%$. Pengujian arus induktor menunjukkan bahwa pada beban induktif, saat menggunakan induktor dengan mode DCM bekerja pada duty cycle $0 \%-80 \%$. Sedangkan saat menggunakan induktor dengan mode CCM bekerja pada duty cycle $41 \%$ - 80\%. Efisiensi tertinggi yang dihasilkan zeta converter beban resistif pada mode CCM sebesar 89,45567\%, sedangkan saat mode DCM sebesar 86,4125\%. Hal ini menunjukkan bahwa mode CCM lebih baik dibandingkan mode DCM jika dilihat dari efisiensi yang dihasilkan. Efisiensi tertinggi yang dihasilkan zeta converter beban induktif pada mode CCM sebesar 91,66287\% sedangkan saat mode DCM sebesar 90,368\%. Hal ini menunjukkan bahwa mode CCM lebih baik dibandingkan mode DCM 
TRANSIENT, VOL. 7, NO. 1, MARET 2018, ISSN: 2302-9927, 7

jika dilihat dari efisiensi yang dihasilkan. Nilai tegangan dan arus keluaran maksimum zeta converter dengan beban resistif pada mode DCM sebesar $49 \mathrm{~V}$ dan $0,75 \mathrm{~A}$ pada saat duty cycle $80 \%$, dan pada mode CCM sebesar 45,3 V dan 0,76 A pada duty cycle $80 \%$. Nilai tegangan dan arus keluaran maksimum zeta converter dengan beban induktif pada mode DCM sebesar 96,3 V dan 0,203 A pada saat duty cycle $80 \%$, dan pada mode CCM sebesar 86,5 V dan 0,189 A pada duty cycle $80 \%$.

\section{Referensi}

[1]. A. P. Nandiwardhana, H. Suryoatmojo, and M. Ashari, "Perancangan Zeta Converter yang dilengkapi Power Factor Correction pada Aplikasi Pengaturan Kecepatan Motor Brushless DC," vol. 5, no. 2, 2016.

[2]. P. R. Babu and S. R. Prasath, "Converter with PID Controller," 2015.

[3]. B. Singh and V. Bist, "Power quality improvements in a zeta converter for brushless DC motor drives," no. July 2014, pp. 351-361, 2015.
[4]. Rashid, M, Power Electronics Circuit, Device, and Aplication $3^{\text {rd }}$, Prentice-Hall International Inc, 2011.

[5]. Daniel W. Hart, "Introduction to Power Electronics, "Printice-Hall International, International Edition, 1997.

[6]. Ervan Kurniawan, Dody, Analisa Power Induktor Bentuk E dengan Kawat Enamel pada Boost Converter, Depok, Universitas Indonesia.

[7]. J. Falin, "Designing DC/DC converters based on ZETA topology," Analog Appl. J. Texas Instruments Inc., vol. 2Q, pp. 16-21, 2010.

[8]. F. A. Nugraha, M. Facta, D. Ph, A. Nugroho, J. T. Elektro, F. Teknik, U. Diponegoro, and J. P. Sudharto, "DAN DCM," pp. 1-10.

[9]. G. Description, V. Range, and C. Diagrams, "LM78XX Series Voltage Regulators LM78XX Series Voltage Regulators," no. February, pp. 1-6, 1995.

[10]. C. Pwm and P. C. Uncommitted, "TL494 Pulse-WidthModulation Control Circuits," 2017.

[11]. FAIRCHILD Semiconductor, MUR1560, 2002.

[12]. I. Power, M. Gate, and T. L. P. I. N. V. T. Inv, "IGBT / Power MOSFET Gate Drive Photo-IC Couplers," vol. 250.

[13]. H. P. Mosfet, "IRFP260N IRFP260N," pp. 1-8.

[14]. S. Wibowo, M. Facta, and A. Nugroho, "CCM DAN DCM,” vol. 4, no. 2, pp. 268-275, 2015 